\title{
The Dichotomized States of Shame in the Scholastic Buddhism
}

\author{
Hao Sun ${ }^{1}$ (D) \\ Accepted: 14 November 2021 / Published online: 29 December 2021 \\ (c) The Author(s) 2021
}

\begin{abstract}
Shame is by and large dichotomized into hrī and (vy)apatrāpya in the Buddhist context. In the Sarvāstivāda and Yogācāra scholasticism, both hrī (in Chinese translation: 慚 cán) and (vy)apatrāpya (in Chinese translation: 愧 kui) are subsumed under the wholesome (kuśala) states (dharmas). In this paper, firstly, previous studies and the etymologies of the two terms above will be closely reviewed; secondly, the exposition and contrast of $h r \bar{t}$ and (vy)apatrāpya between the Sarvāstivāda and Yogācāra will be minutely contextualized; thirdly, the merit of possessing dichotomized states of shame will be thoroughly investigated. Central to my research is a glimpse of the scholastic Indian Buddhist sophistication, exemplified by two kinds of shame, as well as the initial consideration of hri and (vy)apatrāpya in the context of shame, guilt, and conscience in the Anglophone philosophy, while also taking their association with Buddhist morality (síla) and concentration (samādhi) into account.
\end{abstract}

Keywords Shame $\cdot$ Guilt $\cdot$ Buddhist dharmas $\cdot$ Scholastic Buddhism

\section{Background of This Study ${ }^{1}$}

The dichotomized states of shame, $h r \bar{t}$ and (vy)apatrapya, occur frequently in the Buddhist scriptures. Both terms, hrī and (vy)apatrāpya, are chiefly glossed by lajjä/lajjan $\bar{a}{ }^{2}$ meaning 'shame', 'bashfulness', or 'embarrassment'. Nevertheless, these

\footnotetext{
${ }^{1}$ I am deeply grateful to the generous financial support of the German-Israeli Foundation for Scientific Research and Development under the project I-136-107.1-2017 on my current study of the ethical framework for Buddhist meditation practice. I have also deep gratitude to the most valuable suggestions from the reviewers of Journal of Dharma Studies, especially to their advising me on relating shame in the Indian context to the Anglophone philosophy. All errors in this paper remain mine.

${ }^{2}$ According to the authoritative Sanskrit English dictionary, the Monier-Williams Sanskrit English Dictionary, lajjā means 'shame', 'embarrassment', and 'bashfulness'. And the word lajjana is a variant of lajja with the same meaning. Among all the definitions of lajjā, its basic meaning would be 'bashfulness', derived from its verbal root $\sqrt{ }$ lajj, meaning primarily 'turn red in face'.
}

Hao Sun

hao.sun@uni-hamburg.de

1 Numata Center for Buddhist Studies, University of Hamburg, Hamburg, Germany 
two kinds of shame are almost always told apart in the scholastic Buddhism. Shame is in Sanskrit not one concept, just like its complexity and multifacetedness in the Anglophone philosophy. ${ }^{3}$ Starting from the concept of shame, the distinction of 'guiltcultures' and 'shame-cultures' was popularized specially by American anthropologists (Atkins, 1960; Benedict, 1946; Cottingham, 2013; Deigh, 1996). Studies on the shame cultures represent a growing field in this field. In one recent article, it is summarized (Cottingham, 2013) that 'the guilt-cultures of society places great emphasis on ideas of conscience, personal accountability and liability to blame and punishment, while shame-cultures emphasises personal status or standing, as measured in terms of public esteem or its forfeiture'. Whether such contrast of guilt and shame is also related in the Buddhist context is one of my major concerns in this paper. As far as I know, hri and (vy)apaträpya in the scholastic Buddhism are most eligible equivalent terms for comparing to guilt and shame in the Anglophone philosophy.

In Sanskrit, both hrī and (vy)apatrāpya are categorized into wholesome (kuśala) states (dharmas) in the Sarvāstivāda and Yogācāra scholasticism. The existing studies on the wholesome (kuśala) and unwholesome (akuśala) states (dharmas) in the Sarvāstivāda and Yogācāra scholastic Buddhism are also relatively extensive, yet have not particularly focused on certain (pairs or sets of) these Buddhist dharmas. In fact, recent years have witnessed a growing global academic interest in providing an overall feature for the ground-breaking study of these intriguing dharmas in the framework of scholastic Buddhism. Some representative works in this field include Kuśala and Akuśala (Schmithausen, 2013), A Study of the Samskāra Section of Vasubandhu's Pañcaskandhaka (Kramer, 2013), The One Hundred Elements (dharma) of Yogācāra (Saito et al., 2014), and The Seventy-five Elements (dharma) of Sarvāstivāda (Saito et al., 2018). Overall, research on Buddhist dharmas in the context of scholastic Buddhism has received considerable scholarly attention worldwide, and especially in the past ten years.

That being said, the juxtaposition and contextualization of two kinds of shame in the scholastic Buddhist dharmas have hitherto received scant attention by Buddhist scholars, let alone are they put under discussion in association with the shame and guilt cultures mostly interested by American scholars. It is a great pity. However, it also leaves abundant room for me to conduct this study. One might regard inquiry into shame and its related states as weighing too heavily on mind. But for me, the discussion and thorough study of these two Buddhist terms are not oppressive or shameful; rather, it is beneficial. In the scholastic Buddhism, hrī and (vy)apatrāpya are indeed characterized as wholesome (kuśala) dharmas, and their antipodes, two kinds of shamelessness ( $\bar{a} h r \bar{k} k y a$ and anapatrapa $\overline{\text { ) }}$, are designated as unwholesome (akuśala). This lends support to my research. More pragmatically, two kinds of shame (hri and apatrāpya) are credited with being conducing to attaining one

\footnotetext{
3 Many thanks to the kind suggestion from the reviewers of Journal of Dharma Studies, who suggested me to read a paper (Cottingham, 2013) on the complexity of shame and its relationship to conscience and guilt in the Anglophone philosophy. This work enables me to reach a better understanding of these English key words and revise my translation of $h r \bar{l}$ and apatrāpya in the framework of the Anglophone philosophy.
} 
essential Buddhist meditation called samādhi ${ }^{4}$ as illustrated in the Samāhitābhūmi (literally: The Level of Concentration) of the Yogācāra School. The passage on the detailed account of the beneficial factors for attaining samädhi runs in the Samāhitābhūmi as follows ${ }^{5}$ :

What is conducive to samādhi (samādhisāmpreya)? Such as hrī-liked shame, apatrāpya-liked shame, joy and respect (premagaurava), religious confidence and motivation (śraddh $\bar{a}^{6}$ ), right attention (yoniśomanaskāra), mindfulness and clear comprehension (smrtisamprajanya), sensory restraint (indriyasamvara), right conduct of self-discipline (ślasamvara), freedom from regret (avipratisāra) and so on, until pleasure (sukha) as the last one.

The citation above draws our attention to the important role of two kinds of shame, as they strikingly take up the first two positions of the beneficial factors to samädhi meditation. This paramount position again justifies the importance of this study, as not only many scholars are fascinated by the shame and guilt cultures, but also Buddhist practitioners without academic background longing simply for meditative silence would be very interested in this topic. Having prioritized the two kinds of shame for the sake of samādhi meditation, the passage above truly attracts us to further consider the exact meaning and possible divergence of these two Sanskrit terms.

To get a full appreciation of them, I will first turn to its definition in the authoritative Sanskrit dictionary. In A Sanskrit-English Dictionary (Monier-Williams, 1899), $h r \bar{l}$ is translated as 'shame', 'modest', 'shyness', and 'timidity'; while the verbal form apa $\sqrt{ }$ trap for (vy)apatrāpya is construed as 'to be ashamed or bashful'. The definition in the dictionary demonstrates that $h r \bar{l}$ and (vy)apatrāpya are synonyms; each denotes a state of shame. Though the juxtaposition of two kinds of shame is not explicitly clarified, we can somehow get the impression from the Monier-Williams Sanskrit English Dictionary that unlike apaträpya, hri is the kind of shame, largely related to (1) one's moral integrity, as the definition 'modest' conveys and (2) embarrassment, as 'shyness' and 'timidity' suggest. According to the studies conducted by experts on the nuanced contrast of guilt and shame (Atkins, 1960; Cottingham, 2013; Dodds, 1951), 'guilt' system stresses in personal responsibility and inner moral integrity. In this sense, the first layer of $h r \bar{\imath}$ can be well related to the 'guilt' systems, while the second layer of hri conveys to a large extent the embarrassment, in accord with the definition of shame in the broadest sense (Cottingham, 2013).

That the Monier-Williams Sanskrit English Dictionary has not sharply juxtaposed $h r \bar{l}$ and (vy)apatrāpya may well result from the quite undifferentiated usage

\footnotetext{
${ }^{4}$ Vajirañanna (1962) summarized that samādhi signifies the concentration of the mind upon one object, and its chief characteristic is freedom from wavering (p. 34). Adam (2002) added that samädhi is perhaps the broadest term for meditative state. In general, it denotes 'concentration' as a state of non-distraction (p. 38).

5 Its Sanskrit version reads: samādhisāmpreyam katamat? tadyathā hryapatrāpyam premagauravam śraddhā yoniśomanaskārah smrtisamprajanyam indriyasamvarah sỉlasamvaro'vipratisārādayaś ca yāvat sukhaparyavasānāh. See Delhey (Ed.), 2009, § 4.2.3.8.1.

${ }^{6}$ On the thorough study of the term śraddhā, see Zimmermann 2013. On the extensive study of Yogācāra Buddhist theory of metaphor, see Tzohar, 2018.
} 
of these terms in the Mahäbhärata, one of the oldest and longest Indian epics. There the term hri and apatrapa $\bar{a}$ can be both compounded with adhomukha (having face downwards as a gesture of feeling shame). Moreover, according to the previous study (Hara, 2006), on the one hand, the word trapa , which shares the same verbal root with apatrapya, is used in the similar context of $h r \bar{l}$ and expresses in like manner the sense of shame. On the other hand, $h r \bar{l}$ alone can convey one's shame imbued with the sense of pride and honour. It may explain the first layer of $h r \bar{l}$ given in the Monier-Williams Sanskrit English Dictionary. However, in the Mahäbhārata not only trapā, but also lajja (bashfulness or shame) can be interchangeable with $h r \bar{l}$, these terms are often interwoven and not clearly distinguished. It suggests that in the earliest work of Indian epics such notion of dichotomized shame did not exist.

Before some new convincing evidence for the counterargument might emerge in the future, we can give credence to the theory that Buddhist sources for the first time systematized the states of shame. Previous research (Harvey, 2000) shows that a clear distinction of shame is drawn in the Pāli Buddhist literature. There, hiri, the equivalence of Sanskrit $h r \bar{\imath}$, is 'self-respect', which causes one to seek to avoid any action one feels is not worthy of oneself and lowers one's moral integrity. Ottappa, the equivalence of apatrāpya, is 'regard for consequences', being stimulated by concern over reproach and blame for an action (whether from oneself or others), embarrassment before others (especially those people one respects), legal punishment, or the karmic results of an action (p. 11).

When I apply Cottingham's philological studies and analyses to Harvey's interpretation hiri, it appears that the Pāli word hiri is akin to "clear conscience" 7 other than 'guilt conscience'. Clear conscience goes beyond the compass of the term 'shame' could ever cover, because shame is a matter of being 'embarrassed' (Cottingham, 2013, p. 737). It follows that in the Pāli, Buddhist context 'shame' would be not a perfect translation of hiri. Although the term hiri in Pāli Buddhism is not the major concern of this paper, its interpretation of 'self-respect' for $h r \bar{l}$ is echoed in the Sarvāstivāda Buddhist scholasticism. It will be discussed in the third chapter of this paper.

The Pāli Buddhist scriptures initially put forward the contrast of two kinds of shame by providing juxtaposition of their application and semantic contents. The Sanskrit scholastic Buddhism, marked out by Sarvāstivāda and Yogācāra Buddhism, carefully contrived the seventy-five dharmas by the former one hundred dharmas by the latter, aiming at systematizing all the phenomenon, subsuming, and expounding them in their systems. Among the well-devised seventy-five or one hundred dharmas in the scholastic Buddhism, shame is always divided into two: hrī and (vy)apatrāpya with elaborate contrast. In the pages that follow, I will minutely investigate the well work-out dichotomy of shame in the Yogācāra and Sarvāstivāda scholastic Buddhist sources. Not only will I provide English translation for the relevant passages, but also attempt to appreciate the climax of Indian Buddhist exegeses: the scholastic Buddhism, taking two kinds of shame as example. Another main issue of this paper

\footnotetext{
7 A clear conscience occurs "when someone's inner reflection leaves him in the happy position of finding nothing wrong with how he has behaved.” See Cottingham, 2013, p. 731.
} 
is the initial consideration of $h r \bar{l}$ and (vy)apatrāpya in the context of shame, guilt, and conscience in the Anglophone philosophy, while also taking their association with Buddhist morality (ś̄la) and concentration (samādhi) into account.

At this stage, I really do not want to keep the audience in suspense, and wish to preview my following studies on hri and apatrāpya in the Sanskrit scholastic Buddhism. In the Yogācāra scholasticism, hrī denotes guilt-liked shame (lajjā) of one's own accord in his or her transgression. It is guilt-liked shame because it largely accords with the emphasis of guilt on ideas of conscience, personal accountability, and liability (Cottingham, 2013); apatrāpya or its variant vyapatrāpya is in general the shame (lajj $\bar{a})$ out of fear of public blame or bad reputation. This squares more with shame, as shame-cultures emphasize personal status or standing, measured in terms of public esteem or its forfeiture (Cottingham, 2013). By comparison, in the Sarvāstivāda two interpretations of $h r \bar{l}$ and apatrāpya were given: their first explanation is quite complicated and mingled, $h r \bar{l}$ is interpreted as endowed with respect (sagauravatā), veneration (sapratīśatā) and submission to fear (bhayavaśavartitā), while apatrāpya as seeing or perceiving fear (bhayadarśitā) on account of one's own transgression (avadya). Neither of them can be rendered exactly as 'shame', perhaps they are a bit closer to the concept of 'conscience'; however, the second explanation preserved in the Abhidharmakośabhāşya sees nearly eye to eye with the Yogācāra's definition of $h r \bar{\imath}$ and apatrāpya: $h r \bar{\imath}$ (慚 cán) is defined as being blushful/ ashamed in the transgression when considering oneself, and apatrāpya (愧 kui) as being blushful/ashamed in one's own transgression when considering others.

\section{hrī and apatrāpya in the Yogācāra Scholasticism}

Let me take Yogācāra works as a starting point. In the Yogācāra scholasticism, following works are taken into consideration in my paper: (1) the Pañcaskandhaka, which in most cases gives the briefest explanation of the Buddhist dharmas; (2) the Trimssikāvijñaptibhāṣya, which frequently amplifies the explanation in the Pañcaskandhaka; and (3) the Bodhisattvabhūmi and the Samāhitābhümi, the core constituents of the Yogācărabhūmi aiming chiefly not at the elucidation of the Buddhist dharmas, however, incorporating their explication into its works.

First of all, the definition of hri and apatrāpya is given in a brief manner in the Pañcaskandhaka, where two dharmas are both related to bashfulness/shame (lajja $)$ but contrasted sharply as follows ${ }^{8}$ :

What is $h r \vec{\imath}$ ? It is the bashfulness/shame (lajja $)$ with regard to one's own (ätmānam) conduct due to [his or her] transgression (avadya). What is apatrāpya? It is the bashfulness/shame (lajjā) caused by worldly (loka) [judgement] on [one's own] transgression.

\footnotetext{
${ }^{8}$ Its Sanskrit version reads: hrīh katamā? ātmānam dharmaṃ vādhipatim kṛtvā'vadyena lajjā. apatrāpyam katamā? lokam adhipatim krtvā'vadyena lajjā. See Steinkellner and Li (Eds.), 2008, p. 6.7-10.
} 
The passage clearly illustrates that $h r \bar{l}$ and apatrāpya are intimately associated with one common physiological phenomenon in daily life: lajja (bashfulness). When realizing something done wrong by oneself, that person would be bashful. In Sanskrit lajja stems from the verbal root $\sqrt{ }$ lajj, literally means 'to turn red in face' with derived meaning 'to be ashamed'. Here the citation in the Pañcaskandhaka illustrates that some fresh interpretation has been added to the pretty much interchangeable phrases lajj $\bar{a}$, hrī, and apatrāpya in the Mahābhārata. That putting new wine in old bottles by investing well established Sanskrit words with extended meanings is paradigmatic of the scholastic Buddhism. In the Pañcaskandhaka, lajjā (shame/bashfulness) is employed as the gloss or anchor of $h r \bar{l}$ and apatrāpya, while $h r \bar{l}$ is construed as caused by one's own self, apatrāpya as triggered by worldly or better to say social assessment and judgement. And when we apply Cottingham's theory to the Sanskrit terms $h r \bar{i}$ and apatrāpya in this context, $h r \bar{l}$ denotes more precisely the guilt-liked shame than conscience-liked shame, for it arises under the circumstance of one's transgression, but a clear conscience does not need to presuppose one's fault, while apatrāpya encompasses the shame caused by others like worldly judgement. In the Anglophone philosophy, apatrāpya appears to be closer to the semantic domain of shame, as Cottingham (2013) summarized 'shame is being embarrassed seen by others in a setting where your untoward behaviour is the object of a certain class of 'participant-reactive attitudes'.

Secondly, supplemented by an expressive internal monologue and the relationship between shame and one's future conduct, Trimssikavijñaptibhāṣya provided an enlarged exegesis for $h r \bar{\imath}$ and apatrāpya as follows ${ }^{10}$ :

$h r \bar{l}$ is the bashfulness/shame (lajj $\bar{a}$ ) due to [his or her] transgression (avadya) through [facing] oneself or the doctrine [to which one is adhered]. Transgression is actually evil from the nature of being blamed by virtuous people, because of its unfavourable result/consequence. The [sort of] the shame/bashfulness, which is the timidity in mind due to a committed or [yet] not committed transgression, called $h r \bar{\imath}$. It $(h r \bar{\imath})$ has the function of giving basis for restraint from misconduct. apatrāpya is the bashfulness/shame (lajjā) on account of worldly [affairs] (loka) due to [his or her] transgression. One is blushful by the transgression [and] from the fear (bhaya) of being infamous

\footnotetext{
9 Schmithausen (2013) once briefly touched on the definitions of our concern in the Sanskrit Yogācāra sources as ' $h r \bar{\imath}$ is shame one feels of one's own accord, apatrāpya is shame in the sense of being afraid of public blame or bad reputation' (p. 477). I subscribe to his interpretation, and consider that interpretation of $h r \bar{l}$ as 'guilt-liked shame' and apatrāpya as the 'shame caused by others (like worldly judgement)' does well reflect Schmithausen's understanding of these two terms.

${ }^{10}$ I am very grateful to Dr. Toshio Horiuchi for his kind proofreading of my translation. The Sanskrit text reads: hrīr ātmānam dharmạ̣ vādhipatiṃ kṛtvāvadyena lajjā, sadbhir garhitatvād aniștavipākatvāc ca pāpam evāvadyam, tenāvadyena kṛtenākṛtena vā yā cittasyāvalīnatā lajjā sā hrīh, iyañ ca duścari tasaṃyamasamniśrayadānakarmikā. apatrāpyam lokam adhipatim kṛtvāvadyena lajjā, loke hy etad garhitam mām caivam karmāṇam viditvā garhiṣyatīty aślokādibhayād avadyena lajjate, idam api duś caritasamyamasamniśrayadānakarmakam. See Buescher (Ed.), 2007, p. 76.13-20. On the relationship between Triṃśikavijñaptibhāṣya and Pañcaskandhakavibhāṣā, see Kramer, 2016.
} 
(aśloka) and so on, thinking that: "after having known that because I am doingwhat is blamed in the world, one will blame [me]." It (apatrāpya) also has the function of giving basis for restraint from misconduct.

The quotation above shows that Trimssikavijñaptibhāṣya has amplified the definition of $h r \bar{\imath}$ in the Pañcaskandhaka by (1) adding [facing] doctrine (dharma), to which one is adhered, also as the circumstance, under which shame/bashfulness arises in case of $h r \bar{l}$; (2) giving further explanation of transgression (avadya) as being blamed by virtuous people, because of its unfavourable result/ consequence; and (3) extending transgression that is yet not committed also to the cause of shame/being bashful $(h r \bar{l})$, so as to taking precautions against future misconduct.

In case of apatrāpya, it is another sort of the shame/bashfulness, ensuing from the fear of being infamous, due to one's transgression. apatrāpya presupposes the fear of being blamed in the world, though such kind of blame may even not take place, but could just exist in one's mind. It is indeed the fear of being blamed due to one's transgression, that apatrāpya arises. This strengthens my interpretation $h r \bar{\imath}$ and apatrāpya in the earlier part of this chapter: $h r \bar{l}$ is very much analogous to 'guilt-liked shame', while apatrāpya is the shame out of fear of public blame.

It is notable that the function as 'giving basis for restraint from misconduct' was supplemented in the Trimśikavijñaptibhassya for two kinds of shame. This function can lead to upholding morality, though not articulated here. But it is attested in the Bodhisattvabhümi.

Thirdly, the Bodhisattvabhümi has given minute account of vyapatrāpya and then measured it against $h r \bar{\imath}$. The following passage focuses on the relationship between (1) possessing the dichotomized states of shame, (2) upholding morality, and (3) being free of regret ${ }^{11}$ :

In this respect through adopting the [Buddhist] morality (śilasamādāna) from another person, when violating any code of moral discipline (śikșāvyatikrama), a bodhisattva develops vyapatrāpya when comparing with others. Through having an extremely pure attitude towards the morality, a bodhisattva develops $h r \bar{i}$ in comparison with self, when violating any code of moral discipline... In this way, by adopting [the Buddhist morality] and relying on a pure attitude (āśayaviśuddhi) [toward the morality], this bodhisattva generates hri and vyapatrāpya. Through these [dichotomized] states of shame one upholds morality. The one upholding morality is free of regret.

\footnotetext{
$\overline{11}$ Its Sanskrit version reads: tatra paratah śĭlasamādānād bodhisattvasya param upanidhāya śikṣāvyatikrame vyapatrāpyam utpadyate, suviśuddhāśayatayā ś̄̄leșu bodhisattvasyātmānam upanidhāya śikṣāvyatikrame hrīr utpadyate. śikșāpadānām vyatikramapratyāpattyā ādarajātasya cādita evāvyatikramād bodhisattvo dvābhyām ākārābhyām niṣkaukṛtyo bhavati. evam ayam bodhisattvah samādānam āśayaviśuddhiñ ca niśritya hrīvyapatrāpyam utpādayati. hrīvyapatrāpyāt śīlam samāttạ̣ rakșati. rakșamāno niṣkaukrtyo bhavati. See Dutt (Ed.), 1966, p. 95.11-15.
} 
The passage above exhibits the contrast of hri and vyapatrāpya in the first place, their merit as leading to upholding morality, and resulting in being free of regret in the second place. Despite the discussion in the Bodhisattvabhümi ends up there in being free of regret, we can carry on its explication by relating free of regret to the attainment of concentration (samādhi), because the procedure starting from freedom from regret moving towards attaining concentration is well established and widely transmitted in the Buddhist tradition. ${ }^{12}$

Now revert to the benefit of $h r \bar{l}$ and apatrāpya as conducive to concentration (samāahi) in the Samāhitābhūmi, despite that its reason was not explicated there, I postulate that it is the function of giving basis to the restraint from misconduct and consequences of upholding morality and being free from regret that facilitate one's attainment of concentration. Both Bodhisattvabhūmi and Samāhitābhūmi belong to the voluminous Yogācărabhümi, the compendium of the Yogācāra scholasticism.

To summarize, in the Yogācāra scholastic scriptures, $h r \bar{\imath}$ is the guilt-liked bashfulness/shame (lajjā or lajjanā) of one's own accord due to [his or her] transgression (avadya), while (vy)apatrāpya is the bashfulness/shame out of fear (bhaya) of, or respect for (bhayagaurava) others. Both kinds of shame give basis for restraint from misconduct, and further result in upholding one's morality and being free from regret. And this may render their merit as being conducive to attaining concentration (samāahi), as articulated in the Samāhitābhūmi, since upholding morality and being free from regret are integral to concentration in Buddhism.

\section{hrī and apatrāpya in the Sarvāstivāda Scholasticism}

The existent Sarvāstivāda scholastic scriptures ${ }^{13}$ are chiefly preserved in their Chinese translation by Xuanzang 玄奘. The sources of my citations are as follows: (1) 阿毘達磨集異門足論 Ā-pí-dá-mó jú-yì-mén-zú-lùn (the Samgītiparyāyaśāstra), 阿 毘達磨品類足論 $\bar{A}$-pí-dá-mó p̌̌n-lèi-zú-lùn (the Prakaraṇapādaśāstra), and 阿毘

\footnotetext{
12 One example cf. Añguttara Nikāya V,V, see Hardy (Ed.), 1900, p. 312.16-29: Dhammatā esā, bhikkhave, yam sīlavato sīlasampannassa avippațisāro uppajjati... Dhammatā esā bhikkhave, yam avippațisārissa pāmujjạn uppajjati... Dhammatā esā bhikkhave, yam pamuditassa pīti uppajjati... Dhammatā esā bhikkhave, yam pītimanassa kāyo passambhati... Dhammatā esā bhikkhave, yam passaddhakāyo sukham vediyati... Dhammatā esā bhikkhave, yam sukhino cittam samādhiyati. The translation of the above citation from the Anguttara Nikāya $V$ reads: Oh, Bhikkhus, it is natural (dhammatā) that the freedom from regret (avippatisāra) arises in a well-conducted (sīlavat) person...It is natural that gladness arises in a person free from regret...It is natural that joy arises in a person endowed with gladness...It is natural that one endowed with joy eases his/her body...It is natural that a person endowed with ease senses pleasure...It is natural that one concentrates his/her mind when endowed with pleasure. See also Bodhisattvabhümi, cf. Dutt (Ed.), 1966, p. 50.22-23: tathā ślavato'vipratisārah prāmodyam yāvac cittasamādhih̆. The translation of the above quotation from the Bodhisattvabhümi reads: A well-conducted (śllavat) person is free from regret (avipratisāra), that person is glad and up to concentrated (samādhi).

13 On the origin of the Sarvāstivāda scholastic Buddhist tradition, see Willemen et al., 1998, p. xi, 139, 187, 220. On the research review of the relation between Sarvāstivāda and Yogācāra, see Kritzer, 2005, p. xxviii-Xxx.
} 
達磨發智論 $\bar{A}$-pí-dá-mó fā-zhì-lùn (the Jñānaprasthānaśāstra), ${ }^{14}$ (2) 阿毘達磨大 毘婆沙論 $\bar{A}$-pí-dá-mó dà-pí-póshā-lùn (the Abhidharmamahāvibhāṣā), ${ }^{15}$ (3) the Abhidharmakośa and Abhidharmakośabhāsya ${ }^{16}$ (AKBh), and (4) 阿毘達磨順正理 論 $\bar{A}$-pí-dá-mó shun-zhèng-lì-lùn (the *Nyāyānusāraśāstra). ${ }^{17}$ (1) and (2) are known as orthodox Sarvāstivāda scriptures, while (3) and (4) are framed within the broad Sarvāstivāda lineage.

Same as the Yogācāra sources, ${ }^{18}$ hrī and apatrāpya are translated in the $A K B h$ also as 慚 cán and 愧 kuì respectively. The Sanskrit $A K B h$ stated two groups of explanations (kalpa) of $h r \bar{l}$ and apatrāpya. In its first group of explanation, $h r \bar{\imath}$ is interpreted as endowed with respect (sagauravatā), veneration (sapratīśatā), and submission to fear ${ }^{19}$ (bhayavaśavartitā); apatrāpya is rendered as seeing or perceiving fear (bhayadarśitā) on account of transgression (avadya). ${ }^{20}$ Moreover, AKBh added a second group of definition of $h r \bar{l}$ and apaträpya relating them to the root $\sqrt{ }$ lajj, where $h r \bar{l}$ (慚 cán) is defined as being bashful/ashamed in the transgression when considering oneself, apatrāpya (愧 kui) being blushful/ashamed in one's own transgression when considering others. ${ }^{21}$

\footnotetext{
${ }^{14}$ Yaśomitra and Pu Guang, the author of the Abhidharmakośavyākhyā and jù-shě-lùn jì (Note on the Abhidharmakośa) respectively, both mentioned that Jñānaprasthānaśāstra as the body, in the sense of containing the most extensive doctrinal perspectives of the Sarvāstivāda, while Saṃgitiparyāyaśāstra and Prakaraṇapādaśāstra as two of its six feet. According to Pu Guang, Prakaranapādaśāstra was composed in the Buddha's time, Prakaranapādaśāstra around $100 \mathrm{BCE}$, i.e., the third century after the Buddha's demise, see Dhammajoti, 2015, p. 93ff. On the study of the Prakaranapādaśāstra and Jñānaprasthānaśāstra, see also Frauwallner, 1995, p. 14, 26, 36. Prakaranapādaśāstra, Prakaraṇapādaśāstra, and Jñānaprasthānaśāstra are now only existent in Xuanzang's Chinese translation. In the paper, I follow the standard citation formatting of Chinese Buddhist Tripitaka preserved in the Taishō Shinshū Daizōkyō 大正新脩大藏經 (T), that is to say, the Taishō Text number, volume number, page, register, and line number. Thus, for example, T1558: vol. 29, p. 21a22-23 is text number 1558, volume 29, page 21, first register, line 22 to 23 .

15 Subsequent to the definitive establishment of the Sarvāstivāda abhidharma doctrines by Jñanaprasthānaśāstra, there followed active and creative study, discussion, elaboration, and systematization of these doctrines, the result of which was the compilation of Abhidharmamahāvibhāșa, which was composed around the middle of second century A.D and is now only extant in Xuanzang's Chinese translation, see Dhammajoti, 2015, p. 116f.

16 The Abhidharmakośabhāssya is an influential scholastic treatise attributed to Vasubandhu (active in fourth or fifth century A.D). The Abhidharmakośabhāsya consists of two texts: the root text of the Abhidharmakośa, composed in verse (kārikāa), and its prose auto-commentary (bhāşya); this dual verseprose structure comes to be emblematic of later Sarvāstivāda abhidharma literature.

17 The *Nyāyānusāraśāstra is extant only in Chinese translations by Xuanzang. It is intended to safeguard Kāśmīra Vaibhāṣika (one sub-school of the Sarvāstivāda) orthodoxy by demonstrating the erroneous interpretations in Vasubandhu's auto-commentary AKBh. See Willemen et al., 1998, p. 244.

18 In Chinese translation of the Pañcaskandhaka, Abhidharmasamuccaya, Bodhisattvabhūmi, and Samāhitābhūmi, hrī is translated as 慚 cán, apatrāpya/vyapatrāpya as 愧 kuì.

19 In Sanskrit vaśa can mean 'power', 'control' (in Chinese translation 自在 zì-zài), but when it is placed at the latter part of a compound, it means 'controlled by' or 'submitted to'.

20 The corresponding Sanskrit passage cf. AKBh, see Pradhan (Ed.), 1975, p. 60.4-6: viparyayena hrīr apatrāpyam ca veditavyam, pratahamena tāvat kalpena sagauravatā saprațísatā na bhayavaśavartitā (sic) hrīhn, avadyeșv abhayadarśitā (sic)'patrāpyam, dvitīyena kalpenātmaparāpekșābhyām lajjane. Its corresponding Chinese translation of the $A K B h$ (Ā-pí-dá-mó jù-shě-lùn 阿毘達磨俱舍論) see T1558: vol. 29, p. 21a22-23.

21 The Sanskrit passage see AKBh 60.6: dvitīyena kalpenātmaparāpekșābhyām lajjane. Its corresponding Chinese translation of the AKBh (Ā-pí-dá-mó jù-shě-lùn 阿毘達磨俱舍論) see T1558: vol. 29, p. 21a23-25.
} 
It is clear that the second group of explanation of $h r \bar{l}$ and apatrāpya in the $A K B h$ largely squares with the definition in the Yogācāra scriptures as discussed before, whereas the first group of explanation of $h r \bar{l}$ and apatrāpya in the AKBh may have its root in some orthodox Sarvāstivāda works. More precisely, Saṃgītiparyāyaśāstra, Prakaranapādaśāstra, Jñānaprasthānaśāstra, and Abhidharmamahāvibhāșā and the first group of explanation of the $A K B h$ are solid on the definition of $h r \bar{\imath}$ (慚 cán) and apatrāpya (愧 kui). In these works, 慚cán, the Chinese translation of $h r \bar{\imath}$, covers a wide variety of meanings: (1) possessing shame (in Chinese: 有羞 yǒu-xīu, cf. lajjā in the $A K B h$ ), (2) possessing respect $^{22}$ (in Chinese: 有敬 yǒu-jìng, cf. sagauravatā in the AKBh), and (3) possessing the submission to fear (in Chinese: 於自在者有怖畏轉 yú zì-zài-zhě yǒu-bù-wèi-zhuăn, cf. bhayavaśavartitā in the AKBh), while 愧 kuì, the Chinese translation of apatrāpya, encompasses the following dimensions: (1) possessing the sense of shame (in Chinese: 有 恥 yǒu-chř, cf. *lajjā in the $A K B h$ ) and (2) [being able to] perceive fear (in Chinese: [能]見 怖畏 [néng] jiàn-bù-wèi, cf. bhayadarśitā in the $A K B h^{23}$ ). This suggests that the traditional interpretation in the Sarvāstivāda School largely dissents from the outlook of the Yogācāra scholasticism. However, the AKBh, Mahäbhārata, and Pāli sources are on the same page of ascribing respect to the interpretation of $h r \bar{\imath}$; this implies that the same Sanskrit word $h r \bar{l}$ might have undergone some change of primary meanings in the course of history.

That being said, hrī and apatrāpya are analogized in the Abhidharmamahāvibhāṣa to the cloth of dharmakāya on every sentient being in the Form Realm (rūpadhātu), whereas the generality of sentient beings located in the Desire Realm (kāmadhātu) is lack of such cloth due to their absence of hri and apatrāpya, with exception of bodhisattvas and untainted bhikșunis. ${ }^{24}$ The Buddha thus instructs people to cultivate and practice hri and apatrāpya diligently, in order to protect the world. ${ }^{25}$ In

\footnotetext{
${ }^{22}$ The AKBh touched elsewhere upon the relation of $h r \bar{\imath}$ and gurutva as follows: $h r \bar{\imath}$ is respect (gurutva), and respect is with veneration [sapratīsatā]. (Yet), some other schools [argue]: $h r \bar{\imath}$ is the bashfulness/ shame (lajjā) preceded by respect; thus, hrī is not just (eva) respect. See AKBh 60.16-18: gurutvam hrīh, gauravam hi nāma sapratīsatā, tatpūrvikā ca lajjā hrīh. ato na gauravam eva hrīr ity apare. Its corresponding Chinese translation Ā-pí-dá-mó jù-shě-lùn 阿毘達磨俱舍論 see T1558: vol. 29, p. 21b3-6.

${ }^{23}$ The corresponding passage of the Chinese translation of the Samgīitiparyāyasāastra (Ā-pí-dá-mó jí-yì-mén-zúlùn 阿毘達磨集異門足論) see T1536: vol. 26, p. 370a1-9, the Chinese translation of the Prakaranapādaśāstra (Ā-pí-dá-mó pinn-lèi-zú-lùn 阿毘達磨品類足論) see T1542: vol. 26, p. 925a5-10, the Chinese translation of the Jñānaprasthānaśästra (Ā-pí-dá-mó fā-zhì-lùn 阿毘達磨發智論) see T1544: vol. 26, p. 925a5-11, the Chinese translation of the Abhidharmamahāvibhāṣā (Ā-pí-dá-mó dà-pí-pó-shā-lùn 阿毘達磨大毘婆沙論) see T1545: vol.27, p. 180b18-c15, Xuanzang's translation of the Abhidharmakośabhāssya (Ā-pí-dá-mó jù-shě-lùn 阿毘達磨俱舍論) see T1558: vol. 29, p. 21a22-23.

${ }^{24}$ See Chinese translation of the MVŚ (Ā-pí-dá-mó dà-pí-pó-shā-lùn 阿毘達磨大毘婆沙論), T1545: vol. 27, p. 362b14-19: 問中有生時爲有衣不。答色界中有一切有。以色界中慚愧増故。慚愧即是 法身衣服。如彼法身具勝衣服生身亦爾。故彼中有常與衣俱。欲界中有多分無衣。以欲界中多無 慚愧。唯除菩薩及白淨苾夠尼所受中有恒有上妙衣服。Cf. also AKBh, p. 124.13-16: rūpāvacaro'py antarābhavah sampūurnapramānah savastraś ca prādurbhavati, apatrāpyotsadtvāt, bodhisattvasya savastraḥ śuklāyāś ca bhikșunyāh pranidhānavaśäd yāvantam eva parivesțtitā nirdagdhā, anyo nagnah, kāmadhātor anapatrāpyoasadatāt.

${ }^{25}$ See Chinese translation of the MVŚ (Ā-pí-dá-mó dà-pí-pó-shā-lùn 阿毘達磨大毘婆沙論), T1545: vol. 27, p. 180b11-13: 謂慚與愧, 欲顯其相令勤修習。復次如是二法守護世間。如世尊説有二白法能護世 間。謂慚與愧。Cf. also Anguttara Nikāya I, see Morris (Ed.), 1885, p.51.15-21: Dve 'me bhikkhave dhammā sukkā. Katame dve? Hiri ca ottappañ ca. Ime kho bhikkhave dve dhammā sukkā ti. Dve 'me bhikkhave sukkā dhammā lokam pālenti. Katame dve? Hiri ca ottappañ ca. Its English translation reads: Oh, bhikkhus, there are two kinds of bright qualities, namely hiri and ottappa. Oh, bhikkhus, hiri and ottappa protect the world.
} 
comparison, in the exegeses of the $A K B h$, those shameless ones, who are absent of $h r \bar{\imath}$ and apatrāpya, are compared to ones who are drunk. ${ }^{26}$ They are likened to charred seeds and impotent to uphold moralities. ${ }^{27}$

Finally, regarding the time sequence of arousing $h r \bar{l}$ and apatrāpya, the AKBh held that these two are asynchronous, because looking at self and looking at others canot take place at the same time. ${ }^{28}$ On the contrary, *Nyāyānusāraśāstra argued that $h r \bar{l}$ and apatrāpya arise simultaneously. ${ }^{29}$

\section{Conclusion}

In the scholastic Buddhist dharmas, shame is mainly dichotomized into $h r \bar{\imath}$ and (vy)apatrāpya. Both are regarded as wholesome (kuśala) dharma in the Sarvāstivāda and Yogācāra scholasticism. Nevertheless, Sarvāstivāda and Yogācāra dissent from each other on their definition of these two terms.

In the Yogācāra sources, both kind of shame are glossed by one common physiological phenomenon in daily life: lajja or its variant lajjana (bashfulness with shame), whereas $h r \bar{l}$ is very much analogous to 'guilt-liked shame', arising on the occasion of one's transgression after facing oneself or the doctrine, to which one is adhered; (vy)apatrapya is the bashfulness/shame out of fear of being infamous from others' judgement and criticism in one's transgression. Following Cottingham's elucidation of shame and shame-liked states, I provide my working definition 'guilt-liked shame [of one's own accord]' for $h r \bar{t}$, while 'shame [out of fear of others]' for apatrāpya. If we compare hrī and (vy)apatrāpya with the shame and guilt cultures in the Anglophone philosophy, it reveals that $h r \bar{\imath}$ squares more with the notion of guilt, while (vy)apatrāpya more with shame. Possessing shame is not shameful; on the contrary, it is celebrated as wholesome dharmas and factors conducive to concentration (samādhi), one fundamental Buddhist meditation. The function of possessing two kinds of shame is described in the Trimśikavijñaptibhāșya as giving basis for the restraint from misconduct. In the Bodhisattvabhümi, one who possesses $h r \bar{l}$ and (vy)apatrāpya is characterized as upholding morality and being free of regret. These functions form the merits of hrī and (vy)apatrāpya for one's behaviour and cultivation.

Quite the contrary, the Sarvāstivāda School has not related hrī and apatrāpya to samāahi, but hri and apatrāpya were praised as they protect the world. Moreover, the traditional Sarvāstivāda works have interpretated two kinds of shame in a twofold manner. In the first group of interpretation, hri and apatrāpya are not just

\footnotetext{
${ }^{26}$ It reads: 如人醉酒即無慚愧. See T1822: vol. 41, p. 469c20. T1822 俱舍論疏 (Jù-shě-lùn shü) is the commentary of the $A K B h$, composed by 法寶 Fabao in the Tang Dynasty.

27 It reads: 經部答:由身已爲無慚愧壞,無力發戒, 如焦種故不復生芽. See T1821: vol. 41, p. 237b1314. T1821 俱舍論記 (jù-shě-lùn jì) is the commentary of the $A K B h$ narrated by普光 Puguang in the Tang Dynasty.

28 Its Sanskrit version reads: na khalūcyate yugapad ātmānam param cāpekșata ity. See AKBh 60.1-2, meaning 'We certainly do not say looking at oneself and others is simultaneous (yugapad).'.

29 It reads: 由此慚愧, 一心並生. See the Chinese translation of the Nyāyānusāraśāstra (Ā-pí-dá-mó shùn-zhèng-lĭ-lùn 阿毘達磨順正理論), T1562: vol. 29, p. 393b17.
} 
shame: $h r \bar{\imath}$ (慚 cán) covers a wider range of (1) possessing shame, (2) possessing respect, (3) possessing the submission to fear; while apatrāpya (愧 kui) is construed as (1) possessing the sense of shame and (2) [being able to] see or perceive fear. In the second group of interpretation, which correspond closely to their explanation in the Yogācāra sources, $h r \bar{\imath}$ is explained as shame/bashfulness (lajjanā) when considering oneself, apatrāpya as shame/bashfulness (lajjanā) when considering others. It appears that my working translation of $h r \bar{\imath}$ as 'guilt-liked shame [of one's own accord]' and apatrāpya as 'shame [out of fear of others]' can only be partly applied to their second group of interpretation in the Sarvāstivāda sources. The first group of interpretation of $h r \bar{l}$ and apatrāpya is quite conflated, but it may well reflect the traditional Sarvāstivāda exegeses on these terms, revealed by the majority of existent Sarvāstivāda sources. And when we put the first group of interpretation under the microscope, the AKBh, Mahābhärata, and Pāli sources are on the same page of attributing respect to the interpretation of $h r \bar{i}$. And in case of apatrāpya (愧 kuì), it overlaps the feeling of shame. The Sanskrit terms hri and apatrāpya must have undergone the change of their primary meanings in the different contexts in the course of history.

The Chinese translation hrī and apatrāpya would be one typical example of Chinese reception of Buddhist terminology into its culture. More than one thousand years has passed since the dichotomized states of shame were first translated into Chinese as 慚 cán and 愧 kuì. In modern Chinese 慚 cán connotates the worm of conscience arising when a person realizes he or she cannot meet the requirements set up by him- or herself; 愧 kui connotates the worm of conscience arising when a person realizes he or she canot meet the requirements by others. The distinction of $h r \bar{l}$ and apatrāpya in the Buddhist scholasticism might have well crept into the Chinese language and helped form Chinese philosophy on shame. In fact, in modern Chinese language, 慚愧 cán-kuì is mostly used as one phrase, which exactly means 'shame'. As hrī and (vy)apatrāpya are not easy to distinguish in the Indian context, people in China barely reflect upon the divergence of 慚 cán and 愧 kuì, while using the phrase 慚愧 cán-kuì very often when expressing ashamed, bashful, or embarrassed feelings.

When we talk about the shame, guilt, and conscience cultures in the Anglophone contexts, as far as I know, hri and apatrāpya in the scholastic Buddhism are most eligible Sanskrit equivalent terms. Up to now, these terms are quite understudied. I hope my paper could make some contribution to this study.

Funding Open Access funding enabled and organized by Projekt DEAL.

Open Access This article is licensed under a Creative Commons Attribution 4.0 International License, which permits use, sharing, adaptation, distribution and reproduction in any medium or format, as long as you give appropriate credit to the original author(s) and the source, provide a link to the Creative Commons licence, and indicate if changes were made. The images or other third party material in this article are included in the article's Creative Commons licence, unless indicated otherwise in a credit line to the material. If material is not included in the article's Creative Commons licence and your intended use is not permitted by statutory regulation or exceeds the permitted use, you will need to obtain permission directly from the copyright holder. To view a copy of this licence, visit http://creativecommons.org/licen ses/by/4.0/. 


\section{References}

Adam, M. (2002). Meditation and the Concept of Insight in Kamalaśīla's Bhāvanākramas. PhD dissertation. Faculty of Religious Studies, McGill University.

Atkins, A. W. (1960). Merit and Responsibility: A Study in Greek Values. Clarendon.

Buescher, H. (ed.) (2007). Sthiramati's Trimsśikavijñaptibhāsya: Critical Edition of the Sanskrit Text and its Tibetan Translation. Verlag der Österreichischen Akademie der Wissenschaften.

Benedict, R. (1946). The Chrysanthemum and the Sword: Patterns of Japanese Culture. Houghton Mifflin.

Cottingham, J. (2013). Conscience, guilt, and shame. In Crisp, R. (Ed.), The Oxford Handbook of The History of Ethics (pp. 729-744). Oxford University Press. https://doi.org/10.1093/oxfordhb/9780199545 971.013 .0034

Deigh, J. (1996). The sources of moral agency. Cambridge University Press.

Delhey, M. (Ed.). (2009). Samāhitā bhümih: Das Kapitel über die Meditative Versenkung im Grundteil der Yogācārabhümi. Arbeitskreis für Tibetische und Buddhistische Studien.

Dodds, E. R. (1951). The Greeks and the irrational. University of California Press.

Dhammajoti, K. L. (2015). Sarvāstivāda Abhidharma, (5th ed.). The Buddha-Dharma Centre of Hong Kong.

Dutt, N. (ed.) (1966). Bodhisattvabhūmi: Being the 15th Section of Asañgapāda's Yogācārabhūmi. Jayaswal Research Institute.

Frauwallner, E. (1995). Studies in Abhidharma Literature and the Origins of Buddhist Philosophical Systems. State University of New York Press.

Hara, M. (2006). Hindu concept of shame, Sanskrit lajjā, vrīda, hrī. Indologica Taurinensia, 32, 141-196.

Hardy, E. (Ed.). (1900). The Añguttara Nikāya. Pali Text Society.

Harvey, P. (2000). An introduction to Buddhist Ethics: Foundations. Cambridge University Press.

Kramer, J. (2013). A study of the Samskāra section of Vasubandhu's Pañcaskandhaka (with reference to its Commentary by Sthiramati). In U. Kragh (Ed.), The foundation for yoga practitioners: The Buddhist Yogācārabhūmi treatise and its adaptation in India, East Asia, and Tibet (pp. 920-970). Harvard University Press.

Kramer, J. (2016). Some Remarks on Sthiramati and his Putative Authorship of the Madhyāntavibhāgațīā, the *Sūtrālaṃkāravṛttibhāṣya and the Triṃśikāvijñaptibhāṣya. Buddhist Studies Review, 33(1-2), 47-63.

Kritzer, R. (2005). Vasubandhu and the Yogācārabhūmi: Yogācāra Elements in the Abhidharmakośabhāṣya. International Institute for Buddhist Studies.

Monier-Williams, Monier (ed.) (1899). A Sanskrit-English Dictionary: Etymologically and Philologically Arranged with Special Reference to Cognate Indo-european Languages. Clarendon Press.

Morris, R. (Ed.). (1885). The Añguttara Nikāya. Pali Text Society.

Pradhan, P. (ed.) (1975). Abhidharmakośabhāșyam of Vasubandhu (Revised Second Edition with Introduction and Indices by Aruna Haldar). Jayaswal Research Institute.

Saito, A., Daigo. I., Koichi, T., Toshio, H., Hisataka, I., Kuninori, M., Shiori, I. (2014). Bauddhakośa: a treasury of Buddhist terms and illustrative sentences, the one hundred elements (dharma) of Yogācāra in the Abhidharmasamuccaya and Pañcaskandhaka. The Sankibo Press.

Saito, A., Daigo, I., Koichi, T., Kojiro, K., Toshio, H., Hisataka, I., Kuninori, M. (2018). The Seventy-five elements (dharma) of Sarvāstivāda in the Abhidharmakośabhāṣya and Related Works. Bauddhakośa: a treasury of Buddhist terms and illustrative sentences. International Institute for Buddhist Studies.

Schmithausen, L. (2013). Kuśala and Akuśala: reconsidering the original meaning of a basic pair of terms of Buddhist spirituality and ethics and its development up to early Yogācāra. Kragh, T. U. (Ed.), The Foundation for Yoga Practitioners: The Buddhist Yogācārabhūmi Treatise and Its Adaptation in India, East Asia, and Tibet (pp. 440-495). Harvard University Press.

Steinkellner, E., \& Li, X. (Eds.). (2008). Vasubandhu's Pañcaskandhaka. House; Austrian Academy of Sciences Press.

T: Taishō Shinshū Daizōkyō 大正新脩大藏經 (SAT 2015 Version).

Tzohar, R. (2018). A Buddhist Yogācāra theory of metaphor. Oxford University Press. 
Vajirañāna, P. (1962). Buddhist meditation in theory and practice: a general exposition according to the Pāli Canon of the Theravāda School. M. D. Gunasena.

Willemen, C., Dessein, B. and Cox, C. (1998). Sarvāstivāda Buddhist Scholasticism. Brill.

Zimmermann, M. (2013). The chapter on right conduct in the Bodhisattvabhūmi. In U. Kragh (Ed.), The Foundation for Yoga Practitioners: The Buddhist Yogācārabhūmi Treatise and Its Adaptation in India, East Asia, and Tibet (pp. 872-883). Harvard University Press.

Publisher's Note Springer Nature remains neutral with regard to jurisdictional claims in published maps and institutional affiliations. 